\title{
THERAPY OF MAJOR ECTOPARASITOSES IN GRASSCARP (CTENOPHARYNGODON IDELLA) FRY AND FINGERLINGS
}

\author{
J. WILLOMITZER
}

Veterinary Research Institute, 62132 Brno

Received March 28, 1980

\begin{abstract}
Willomitzer J.: Therapy of Major Ectoparasitoses in Grasscarp (Ctenopharyngodon idella) Fry and Fingerlings. Acta vet., 49, 1980: 279-282.

Dipping, short-term and long-term baths in solutions of common substances (potassium permanganate, formaline, common salt) currently recommended for the control of ectoparasites of the genera Chilodonella, Trichodinella and Dactylogyrus in grasscarp fry and fingerlings were tested under laboratory conditions. Dipping into a 1: 1000 diluted potassium permanganate bath for 45 seconds was 100 per cent effective against Trichodinella spp. Short-term baths in a $1: 2500$ formaline solution for 60 minutes was 100 per cent effective against Chilodonella spp., Trichodinella spp. and Dactylogyrus spp., but 23.3 per cent of the treated fish died. The best results in the control of Chilodonella spp. and Trichodinella spp. in grasscarp fingerlings from the 3rd week after hatching were obtained with long-term baths in a 0.7 per cent solution of common salt for 21 to 24 hours.
\end{abstract}

Chilodonellosis, trichodinellosis, dactylogyrosis, intensity of infection, formaline bath, salt bath.

During our previous studies on parasitic diseases of herbivorous fish it became clear that grasscarp (Ctenopharyngodon idella) fry and fingerlings in Czechoslovakia were infected mainly with Chilodonella spp., Trichodinella spp. and Trichodina spp. These parasites attack the fry as early as 1 to 3 weeks after hatching and cause an impairment of the hosts. These infestations are followed by infection with Dactylogyrus spp. (Willomitzer 1980).

Antiparasitic dipping baths recommended for the control of the aforementioned parasites were tested on a small number of grasscarp by Tesarčík and Ehl (1968). They found that dipping into a $1: 1000$ diluted permanganate bath for 30 to 45 seconds at $10.5{ }^{\circ} \mathrm{C}$ water temperature, $\mathrm{pH}$ 6.15, was well tolerated by grasscarp. The same applied to dipping into a $1: 1000$ diluted ammonia or trypaflavine bath for 2.5 minutes at $13^{\circ} \mathrm{C}$ water temperature.

According to Musselius (1962) short-term salt baths for 5 minutes in 5 per cent $\mathrm{NaCl}$ can be used at a water temperature up to $15^{\circ} \mathrm{C}$, but are a hazard for herbivorous fish at higher temperatures. Tesarčík and Ehl (1968), in their exploratory experiments with salt baths, recorded an increased respiratory rate and excitation of the experimental fish. They reported good experience with short-term baths in malachite green at the concentration of $1: 150000$ for 1.5 hours at $12.5^{\circ} \mathrm{C}$ water temperature.

Bauer et al. (1963) controlled ectoparasites by long-term baths in 0.6 per cent $\mathrm{NaCl}$ for 18 hours. Ljubimov (1975) developed a method of exact chlorine dosing for the control of chilodonellosis, trichodinosis and costiasis in wintering ponds.

The finding in our country of increasing infection of grasscarp fry and fingerlings with ectoparasites of the genera Chilodonella, Trichodinella and Dactylogyrus at the State Fishery, Pohorelice in 1978-1979 prompted us to evaluate under laboratory conditions some of the treatments recommended for the control of these parasites. 


\section{Materials and Methods}

The experiments were carried out on grasscarp fry and fingerlings kept in all-glass 19.9 litre aquariums, 9-35 fish to an aquarium. The effectiveness of the baths was evaluated in terms of extensive effectiveness, i.e. the percentage of parasite-free fry and fingerlings in treated aquariums relative to the number of parasitized fry and fingerlings in control aquariums. At each therapeutic bath measurements were made of water temperature and $\mathrm{pH}$. The intensity of infection with protozoa was evaluated on the basis of the parasite number seen in the microscopic field, using $\mathbf{a}+$ to +++ scale where,+++ and +++ indicate solitary protozoa, more than 10 protozoa and more than 100 protozoa, respectively. The intensity of infection with monogenetic trematodes was evaluated according to the number of parasitized fry and fingerlings and on the basis of total trematode number found on the left and right gills of experimental fish.

The baths tested were as follows: dipping potassium permanganate baths, short-term formaline baths and long-term salt baths.

\section{Results}

Dipping into a $1: 1000$ diluted potassium permanganate bath was 100 per cent effective against Trichodinella spp., less effective (78 per cent) against Chilodonella spp. and little effective (25 per cent) against Dactylogyrus spp.

Short-term baths in a 1:5000 formaline solution for 15 minutes were ineffective against Dactylogyrus spp. and were not evaluated as to their efficiency against Chilodonella spp. and Trichodinella spp. Only after formaline concentration was increased to $1: 2500$ and exposure extended to 60 seconds, the bath became 100 per cent effective against Dactylogyrus spp., Chilodonella spp. and Trichodinella spp., but 23.3 per cent of the treated fish died.

Long-term baths in a 0.7 per cent solution of common salt for 21 to 24 hours were 100 per cent effective against Chilodonella spp. and Trichodinella spp., but were inefficient against Dactylogyrus spp. in grasscarp fry 0.1 to $6.6 \mathrm{~g}$ in body mass (Table 1).

Table 1

Survey of therapeutic treatments in grasscarp fry and fingerlings (body mass $0.04-121.1 \mathrm{~g}$; water temperature $23^{\circ} \mathrm{C}$; $\mathrm{pH} 6.0$ )

Dipping baths

\begin{tabular}{|c|c|c|c|c|c|c|c|c|c|}
\hline \multirow{2}{*}{ Group } & \multirow{2}{*}{$\begin{array}{l}\text { No. of fry } \\
\text { or finger- } \\
\text { lings }\end{array}$} & \multicolumn{3}{|c|}{ No. infected with } & \multirow{2}{*}{ Drug } & \multirow{2}{*}{$\begin{array}{l}\text { Concen- } \\
\text { tration }\end{array}$} & \multirow{2}{*}{$\begin{array}{l}\text { Treatment } \\
\text { duration }\end{array}$} & \multirow{2}{*}{$\begin{array}{l}\text { No. of } \\
\text { deaths }\end{array}$} & \multirow{2}{*}{$\begin{array}{l}\text { Extensive } \\
\text { effectiveness }\end{array}$} \\
\hline & & $\mathrm{C}^{*}$ & $\mathrm{~T}$ & $\mathrm{D}$ & & & & & \\
\hline $\begin{array}{l}\text { Treated } \\
\text { Control }\end{array}$ & $\begin{array}{l}30 \\
30\end{array}$ & $\begin{array}{l}2 \\
9\end{array}$ & $\overline{25}$ & $\begin{array}{r}9 \\
12\end{array}$ & $\mathrm{KMnO}_{4}$ & $1: 1000$ & 45 second & 3 & $\begin{array}{ll}\text { C } & 78 \\
\text { T } & 100 \\
\text { D } & 25\end{array}$ \\
\hline \multicolumn{10}{|c|}{ Short-term baths } \\
\hline $\begin{array}{l}\text { Treated } \\
\text { Treated } \\
\text { Control }\end{array}$ & $\begin{array}{l}35 \\
30 \\
35\end{array}$ & $\frac{-}{15}$ & $\begin{array}{l}- \\
\overline{22}\end{array}$ & $\frac{8}{7}$ & $\begin{array}{c}\text { formaline } \\
\text { formaline } \\
-\end{array}$ & $\begin{array}{c}1: 5000 \\
1: 2500 \\
-\end{array}$ & $\begin{array}{l}15 \text { minutes } \\
60 \text { minutes }\end{array}$ & $\begin{array}{r}2 \\
7 \\
-\end{array}$ & $\begin{array}{llll}\mathrm{D} & 0 & & \\
\mathrm{D} & 100 & & \\
\mathrm{C} & 100 & \mathrm{~T} & 100\end{array}$ \\
\hline \multicolumn{10}{|c|}{ Long-term baths } \\
\hline $\begin{array}{l}\text { Treated } \\
\text { Control }\end{array}$ & $\begin{array}{l}15 \\
18\end{array}$ & $\overline{1}$ & $\overline{4}$ & - & $\underset{-}{\mathrm{NaCl}}$ & $0.7 \%$ & $\begin{array}{c}21 \text { hours } \\
-\end{array}$ & $\overline{-}$ & $\begin{array}{l}\text { C } 100 \\
\text { D - }\end{array}$ \\
\hline
\end{tabular}

* $\mathrm{C}=$ Chilodonella spp., $\mathrm{T}=$ Trichodinella spp., $\mathrm{D}=$ Dactylogyrus spp. 
The efficiency of long-term baths in a 0.7 per cent common salt solution against Chilodonella spp. and Trichodinella spp. was assessed in addition in relation to the intensity of infection (Table 2). The treatment proved 100 per cent effective even under conditions of the highest $(+++)$ intensity of infection.

Table 2

Efficiency of $0.7 \mathrm{NaCl}$ against protozoa in grasscarp fry (body mass, $0.1-6.6 \mathrm{~g}$, water temperature, $23^{\circ} \mathrm{C}, \mathrm{pH} 5.4$ )

\begin{tabular}{|c|c|c|c|c|c|c|c|c|}
\hline \multirow{2}{*}{$\begin{array}{l}\text { Experiment } \\
\text { No. }\end{array}$} & \multirow{2}{*}{ Group } & \multirow{2}{*}{ No. of fry } & \multicolumn{2}{|c|}{$\begin{array}{l}\text { No. infected } \\
\text { with }\end{array}$} & \multirow{2}{*}{$\begin{array}{c}\text { Treatment } \\
\text { duration } \\
\text { (hours) }\end{array}$} & \multirow{2}{*}{$\begin{array}{l}\text { No. of } \\
\text { deaths }\end{array}$} & \multirow{2}{*}{$\begin{array}{c}\text { Extensive } \\
\text { effectiveness }\end{array}$} & \multirow{2}{*}{$\begin{array}{l}\text { Intensity } \\
\text { of infection }\end{array}$} \\
\hline & & & $\mathrm{C}^{*}$ & $\mathrm{~T}$ & & & & \\
\hline 1 & $\begin{array}{l}\text { Treated } \\
\text { Control }\end{array}$ & $\begin{array}{l}17 \\
16\end{array}$ & $\overline{2}$ & $\overline{3}$ & 22 & $\overline{-}$ & $\begin{array}{ll}\text { C } & 100 \\
\text { T } & 100\end{array}$ & + \\
\hline 2 & $\begin{array}{l}\text { Treated } \\
\text { Control }\end{array}$ & $\begin{array}{r}9 \\
10\end{array}$ & $\overline{1}$ & $\overline{6}$ & 21 & - & $\begin{array}{ll}\text { C } & 100 \\
\text { T } & 100\end{array}$ & +++ \\
\hline 3 & $\begin{array}{l}\text { Treated } \\
\text { Control }\end{array}$ & $\begin{array}{l}23 \\
23\end{array}$ & $\overline{1}$ & $\overline{23}$ & 24 & $\overline{-}$ & $\begin{array}{ll}\text { C } & 100 \\
\text { T } & 100\end{array}$ & +++ \\
\hline 4 & $\begin{array}{l}\text { Treated } \\
\text { Control }\end{array}$ & $\begin{array}{l}12 \\
26\end{array}$ & $\begin{array}{l}- \\
-\end{array}$ & $\overline{16}$ & 21 & - & $\begin{array}{l}\mathrm{C} \\
\mathrm{T}\end{array} \overline{100}$ & ++ \\
\hline
\end{tabular}

* $\mathrm{C}=$ Chilodonella spp., $\mathrm{T}=$ Trichodinella spp.

\section{Discussion}

In the present study a number of common agents recommended in the literature for the control of fish ectoparasites were tested for efficiency against selected ectoparasites (Chilodonella spp., Trichodinella spp. and Dactylogyrus spp.) in grasscarp fry and fingerlings. In contrast to the observations of Tesarčík and Ehl (1968) who found that baths in 1:1000 diluted permanganate for 30 to 45 seconds were well tolerated by grasscarp, a degree of toxicity of this compound became apparent in our experiments where 3 out of 30 fry and fingerlings died. Another disadvantage of the permanganate baths was that though 100 per cent efficient against Trichodinella spp., it was ineffective against the other ectoparasites.

Formaline baths, traditionally recommended for the control of fish ectoparasites, were 100 per cent effective against the three major ectoparasites of grasscarp fry and fingerlings, namely Chilodonella spp., Trichodinella spp. and Dactylogyrus spp., but would be of no value in the field in view of the high mortality rate (23.3 per cent) among the treated grasscarp fry and fingerlings.

The results confirmed the usefulness of long-term common salt baths employed for the control of ectoparasites in grasscarp by Bauer et al. (1963). However, the successful therapy of chilodonellosis and trichodinellosis in the present study was obtained with a slightly higher $(0.7$ per cent $)$ common salt concentration and longer duration (21-24 hours) of the bath.

\section{Terapie závažných ektoparazitóz u plůdku amura bílého (Ctenopharyngodon idella)}

Prověřovali jsme účinnost ponořovací lázně, krátkodobých a dlouhodobých koupelí při použití běžných prostředků (manganistan draselný, formalin, kuchyňská sůl) proti ektoparazitům rodu Chilodonella, Trichodinella a Dactylogyrus u plůdku 
amura bílého. Ponořovací lázeň s manganistanem draselným v koncentraci $1: 1000$ při expozici $45 \mathrm{~s}$ měla vysokou účinnost $(100 \%)$ na Trichodinella. Krátkodobá koupel ve formalinu v koncentraci $1: 2500$ při expozici $60 \mathrm{~min}$. měla vysokou účinnost proti Chilodonella, Trichodinella a Dactylogyrus, avšak působila nepříznivě na ryby $(23,3 \%$ úhyn ryb). Nejlépe se osvědčily dlouhodobé koupele v $0,7 \%$ roztoku kuchyňské soli při expozici $21-24$ hodin proti Chilodonella a Trichodinella u plůdku ve stárí od 3. týdne.

\section{Терапия важных эктопаразитозов у мальков Ctenopharyngodon idella}

Нами проверялась эффективность погружных ванн, кратковременных и длительных ванн с использованием обычных средств (перманганата калия, формалина, поваренной соли) против эктопаразитов рода Chilodenella, Trichodinella и Dactylogyrus у мальков Ctenopharyngodon idella. Ванна с манганатом калия с конщентрацией 1:1000 при әкспозиции 45 отличалась высокой эффективностью (100\%) по отношению к Триходинелла. Кратковременная ванна в формалине с концентрацией 1:2500 при экспозиции 60 минут отличалась высокой эффективностью по отношению к Chilodonella, Trichodinella и Dactylogyrus, однако, она оказывала неблагоприятное влияние на рыбы (отход рыб 23,3 \%). Лучше всего оправдали себя длительные ванны в растворе поваренной соли $0,7 \%$ с әкспозицией $21-24$ часа против Chilodonella и Trichodinella у мальков в возрасте с 3 недель.

\section{References}

BAUER, O. N. - BABAJEV, B. - STRELKOV, J. A.: Parazitarnye zabolevanija belogo amura i tolstolobika pri vyraščivanii v prudach. In: Problemy parazitologii. Kijev 1963: 439-440.

LJUBIMOV, E. A.: Protozojnye bolezni ryb v zimovalnych bassejnach. Veterinarija, 52, 1975, $10: 68-70$.

MUSSELIUS, V. A.: Parazity i bolezni rastitelnojadnych ryb i mery borby s nimi. Moskva 1967.

TESARCfK, J. - EHL, A.: Antiparazitárni a protiplísňové koupele a ekonomicky závažná onemocnění a parazitózy nově aklimatizovaných ryb. Buletin VÚR Vodňany, 4, 1968: 19-26.

WILLOMITZER, J.: Seasonal Dynamics of Parasitoses in Grasscarp (Ctenopharyngodon idella) Fry and Fingerlings. Acta vet. Brno, 1980 (in press). 